\title{
Risk profiling of schistosomiasis using remote sensing: approaches, challenges and outlook
}

\author{
Yvonne Walz ${ }^{1,2^{*}}$, Martin Wegmann ${ }^{1}$, Stefan Dech ${ }^{1,3}$, Giovanna Raso ${ }^{4,5}$ and Jürg Utzinger ${ }^{4,5}$
}

\begin{abstract}
Background: Schistosomiasis is a water-based disease that affects an estimated 250 million people, mainly in sub-Saharan Africa. The transmission of schistosomiasis is spatially and temporally restricted to freshwater bodies that contain schistosome cercariae released from specific snails that act as intermediate hosts. Our objective was to assess the contribution of remote sensing applications and to identify remaining challenges in its optimal application for schistosomiasis risk profiling in order to support public health authorities to better target control interventions.

Methods: We reviewed the literature (i) to deepen our understanding of the ecology and the epidemiology of schistosomiasis, placing particular emphasis on remote sensing; and (ii) to fill an identified gap, namely interdisciplinary research that bridges different strands of scientific inquiry to enhance spatially explicit risk profiling. As a first step, we reviewed key factors that govern schistosomiasis risk. Secondly, we examined remote sensing data and variables that have been used for risk profiling of schistosomiasis. Thirdly, the linkage between the ecological consequence of environmental conditions and the respective measure of remote sensing data were synthesised.

Results: We found that the potential of remote sensing data for spatial risk profiling of schistosomiasis is - in principle - far greater than explored thus far. Importantly though, the application of remote sensing data requires a tailored approach that must be optimised by selecting specific remote sensing variables, considering the appropriate scale of observation and modelling within ecozones. Interestingly, prior studies that linked prevalence of Schistosoma infection to remotely sensed data did not reflect that there is a spatial gap between the parasite and intermediate host snail habitats where disease transmission occurs, and the location (community or school) where prevalence measures are usually derived from.
\end{abstract}

Conclusions: Our findings imply that the potential of remote sensing data for risk profiling of schistosomiasis and other neglected tropical diseases has yet to be fully exploited.

Keywords: Ecology, Epidemiology, Geographical information system, Intermediate host snail, Remote sensing, Risk profiling, Scale, Schistosomiasis, Spatial modelling

\section{Background}

Schistosomiasis is a parasitic disease of humans and animals caused by blood flukes of the genus Schistosoma. From a public health perspective, schistosomiasis is the most important water-based disease [1]. Global statistics suggest that an estimated 779 million people are at risk

\footnotetext{
* Correspondence: yvonne.walz@uni-wuerzburg.de

'Department of Remote Sensing, Institute for Geography and Geology,

University of Würzburg, Würzburg, Germany

${ }^{2}$ United Nations University - Institute for Environment and Human Security,

Bonn, Germany

Full list of author information is available at the end of the article
}

of schistosomiasis [1], about 250 million people are currently infected, mainly in sub-Saharan Africa [2], and the global burden of schistosomiasis is 3.3 million disability-adjusted life years (DALYs) [3]. Transmission of schistosomiasis is spatially and temporally restricted to freshwater bodies inhabited by specific intermediate host snails, which act as disease vectors by shedding cercariae. Schistosomiasis is an environmental disease and remote sensing technologies can deepen our understanding of environmental drivers in relation to the spatial and temporal distribution [4]. Figure 1 illustrates the 

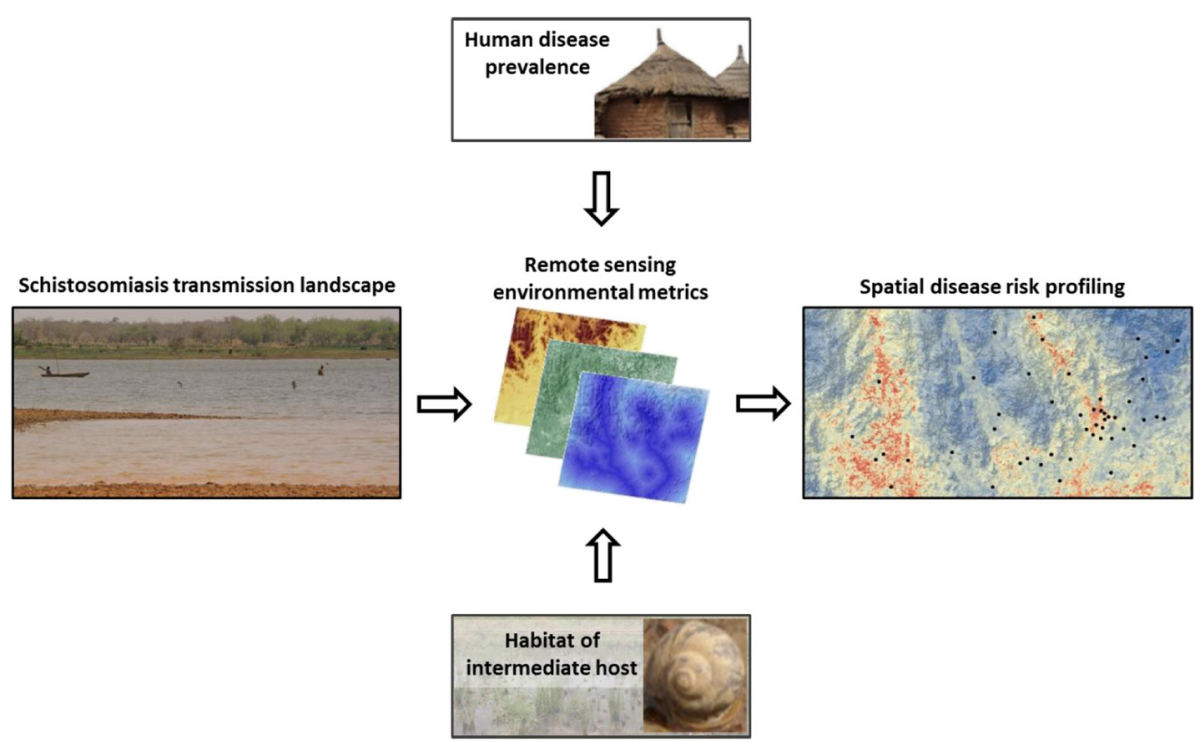

Figure 1 Conceptual framework of schistosomiasis risk profiling using remote sensing data. Remote sensing data measure environmental conditions that describe landscape parameters relevant for disease transmission. The information of suitable habitat conditions for intermediate host snails and Schistosoma parasites or survey measurements of human disease prevalence provide the reference of remotely sensed environmental metrics. Based on this established relation, remotely sensed environmental conditions can predict the risk of disease transmission in geographical space.

conceptual framework adopted here for spatially explicit schistosomiasis risk profiling using remote sensing data.

Over the past 30 years, the use of remote sensing data and techniques in mapping environment-related diseases, including schistosomiasis, has increased considerably [5]. The wealth of scientific literature contains a set of case studies that investigated the usefulness of various satellite data and variables with their spatial and temporal properties for selected geographical regions of the world and in relation to specific diseases or disease agents such as intermediate hosts, parasites or vectors [5-12]. Since those agents have specific requirements regarding climate, vegetation, soil and other edaphic factors, and are sensitive to changes therein, remote sensing can be used to determine the living conditions of these agents and predict potential distributions of their habitats (for definition, see Table 1) [13].

It is important to note that there is a complex linkage between ecological habitat conditions of disease-related parasites and intermediate host snails, relevant measurements of remote sensing data and infection of humans, which has not yet been analysed and reviewed by different groups that bridge professional expertise of the respective disciplines [16]. For example, it has never been specified what different remote sensing measurements (e.g. normalized difference vegetation index (NDVI)) exactly detect with regard to the ecological context of schistosomiasis transmission. However, a detailed understanding of the respective measurements from each discipline against the contextual background of disease transmission depicted in Figure 1 is necessary to optimise its application and improve spatial risk (for definition, see Table 1) assessment and prediction.

The aim of this review was to build a bridge between the knowledge gathered between different disciplines; namely, epidemiology and disease ecology on the one hand and remote sensing measurements used for risk profiling on the other hand. Schistosomiasis serves as the example to connect the different strands of scientific inquiry. We review factors that might govern the transmission of schistosomiasis, placing particular attention to remote sensing applications for risk profiling. In this regard, our review builds upon the work of Simoonga et al. [11] and is complemented with a detailed analysis

Table 1 Important terms and definitions employed in the current review

\begin{tabular}{|c|c|}
\hline Term & Definition \\
\hline Risk & $\begin{array}{l}\text { Defined as effect of uncertainty on objectives } \\
\text { (International Organization of Standardization (ISO) } 31000 \text { : } \\
\text { Risk management) and implies a future event with an } \\
\text { uncertainty if and how the entity of interest is affected by } \\
\text { a certain phenomenon. For this research, risk is defined as } \\
\text { probability of humans to become infected with the } \\
\text { parasite. }\end{array}$ \\
\hline Environment & $\begin{array}{l}\text { In a medical sense, integrates all factors external to } \\
\text { humans but interacts with them, e.g. physical, biological, } \\
\text { social and cultural environment [14]. With respect to the } \\
\text { parasite and snail species, environment includes biotic } \\
\text { and abiotic phenomena surrounding and potentially } \\
\text { interacting with the organisms [15]. }\end{array}$ \\
\hline
\end{tabular}

Habitat Description of a physical place (i.e. a geographical space), at a particular scale of space and time, where an organism either actually or potentially lives [15]. 
of remote sensors, sensor combinations and specific variables that have been used to date for schistosomiasis risk profiling.

\section{Factors that govern schistosomiasis risk}

Risk of schistosomiasis is defined as the probability of humans becoming infected with Schistosoma during contact with infested freshwater bodies. The rate of human infection is fundamentally governed by suitable conditions for disease transmission from human to human, which integrates factors that determine the parasite life cycle, its intermediate host snail and its definitive human hosts, as illustrated by King [17]. The impact of relevant disease transmission factors on the ecology of the parasite, intermediate host snail and human host infection are summarised in Table 2 and described in more detail in the following paragraphs.

\section{Schistosoma parasites}

There are six schistosome species parasitising humans; S. haematobium, S. mansoni, S. japonicum, S. intercalatum, S. mekongi and S. guineensis. The current review focuses on the former two, which are the most widespread and affect tens of millions of people, particularly in sub-Saharan Africa [46].

Water temperature has a major influence on the prepatent period of Schistosoma, which is related to its abundance in the environment. However, the relevant temperature thresholds vary between different stages of parasite development. Eggs of the parasite hatch at temperatures ranging between $10^{\circ} \mathrm{C}$ and $30^{\circ} \mathrm{C}$ [18]. The period from penetration of the miracidium to initial shedding of cercariae by the snail varies with temperature between the minimum of 17 days at $30-35^{\circ} \mathrm{C}$ and several months at lower temperatures. Laboratory investigations found an inverse relationship between the length of the prepatent period with water temperature; the developmental null point of parasite development occurred at $14.2^{\circ} \mathrm{C}$ for $S$. mansoni [19] and at $15.3^{\circ} \mathrm{C}$ for $S$. haematobium [47]. The maximum of $S$. haematobium cercarial shedding was observed at water temperatures around $25^{\circ} \mathrm{C}$ [47].

Water flow velocity influences the spatial distribution of the parasite. Stagnant water contains the highest cercarial density, whereas flowing water can transport the parasite passively for considerable distances [20]. Very slow moving water with a speed of approximately $0.1 \mathrm{~m} / \mathrm{s}$ is beneficial to allow the widespread dissemination of the parasite, which in turn enhances the odds of finding a suitable intermediate host snail $[27,48]$. Interestingly, active parasite mobility has been observed to be stimulated by various components of sweat secreted by humans $[49,50]$.
Natural predators such as fish, and diverse carnivorous invertebrates, feed on the miracidia, and hence, they may reduce parasite abundance [20,21]. Sunlight is a particular stimulus for the release of cercariae from infected snails, whereas the number of cercariae produced is mainly influenced by the size of the snail and the water temperature [19]. Internal factors of the parasite may modify the risk of infection such as different genetic strains resulting in different pathogenicity. This could account for the observed geographical variations in severity of human schistosomiasis [22]. The efficiency of snail and human infection varies with species. For example, miracidia of $S$. haematobium, on average, need more individuals to infect their intermediate host snail than those of S. mansoni [19]. Additionally, intermediate host snails of $S$. haematobium are more dispersed than those of $S$. mansoni, which thus result in lower snail infection rates observed in natural freshwater bodies for S. haematobium [19].

\section{Freshwater snails}

To complete a successful life cycle, $S$. haematobium is transmitted almost exclusively by snails of the genus Bulinus, of which, however, only a few species are susceptible [27]. Intermediate hosts of $S$. mansoni belong to the genus Biomphalaria [27]. Both snail genera are pulmonate snails of the Planorbidae family and live in aquatic environments [27].

Similar to the parasite, survival, fecundity and rate of reproduction of freshwater snails are sensitive to water temperature. In contrast to the parasite, snails prefer cooler conditions. Despite snails having broad tolerance ranges of their ambient temperature between day and night and over the course of a year, the most favourable range lies between $18^{\circ} \mathrm{C}$ and $32^{\circ} \mathrm{C}$ [24]. Snails of the genus Bulinus show a distinct peak of maximal reproduction at $25^{\circ} \mathrm{C}$ [25], whereas Biomphalaria have the highest reproduction rates at temperatures ranging from $20^{\circ} \mathrm{C}$ to $27^{\circ} \mathrm{C}[24,26]$. The correlation between thermal regimes and snail fecundity allowed deriving a critical level of $120-179$ degree hours greater than $27^{\circ} \mathrm{C}$ per week. When this critical level was exceeded, snails were absent from a habitat [24]. Indeed, 100\% mortality was observed after exposure of snails to $36^{\circ} \mathrm{C}$ and above within a few days [18]. However, in sub-tropical regions of Africa, the impact of temperature on the limitation of snail distribution is only relevant for very small water bodies exposed to continuous high temperatures [23].

Regarding water flow velocity, freshwater snails have a noticeable narrow tolerance range [24] and become dislodged when flow velocity exceeds approximately $0.3 \mathrm{~m} / \mathrm{s}$ $[24,28]$. A nearly linear, negative correlation between the density of Biomphalaria and water flow velocity was derived until the aforementioned limit [24,28]. It has also 
Table 2 Overview of parasite-, snail- and human-related factors that modify, retain or intensify the cycle of schistosomiasis transmission

\begin{tabular}{|c|c|c|}
\hline Parasite-related factors & Effect on schistosomiasis transmission & Reference(s) \\
\hline Temperature & $\begin{array}{l}\text { Length of prepatent period; activity, survival and infection rate of free-living stages of the } \\
\text { parasite }\end{array}$ & {$[18,19]$} \\
\hline Water flow velocity & Passive transport of parasites in flowing water determines cercarial density & [20] \\
\hline Predators & Fish and carnivorous invertebrates reduce parasite population as natural predators & {$[20,21]$} \\
\hline Sunlight & Stimulation of cercarial shedding & [19] \\
\hline Pathogenicity & $\begin{array}{l}\text { Different strains of S. mansoni and S. haematobium result in geographical variations of } \\
\text { disease severity }\end{array}$ & [22] \\
\hline Species & Different efficiency in identifying and infecting snails & [19] \\
\hline$\underline{\text { Snail-related factors }}$ & Effect on schistosomiasis transmission & Reference(s) \\
\hline Water temperature & Fecundity, mortality and rate of reproduction & {$[18,23-26]$} \\
\hline Water flow velocity & Flow velocity $>0.3 \mathrm{~m} / \mathrm{s}$ may dislodge and swep away snails & {$[24,27,28]$} \\
\hline Vegetation & Food supply, surface to crawl and deposit egg masses; increase of dissolved oxygen & [23] \\
\hline Substratum & Nature of substratum is related to snail abundance & {$[23,24]$} \\
\hline Water depth & $\begin{array}{l}\text { Snails generally found in shallow water near the margins of their habitats; below } 1.5-2 \mathrm{~m} \text {, } \\
\text { snails have little importance for the transmission of schistosomiasis }\end{array}$ & [29] \\
\hline Fluctuations of water level & Permanence of available habitats determines the distribution patterns of snails & {$[23,24]$} \\
\hline Rainfall & $\begin{array}{l}\text { Creation of temporary snail habitats; increase of water flow velocity; supports contamination } \\
\text { of water and passively transports snails when rains are heavy }\end{array}$ & {$[20,24,27]$} \\
\hline Turbidity & Turbidity can impact the reproduction cycle & {$[24,30]$} \\
\hline Water chemistry/quality & $\begin{array}{l}\text { Low pH, refuse from factories directly harm snails; high abundance where water is polluted } \\
\text { with human excrements }\end{array}$ & {$[23,24,27,31]$} \\
\hline Sunlight & $\begin{array}{l}\text { Completely shaded pools provide unsuitable habitat and activity of snails is high in direct } \\
\text { sunlight }\end{array}$ & [23] \\
\hline Predators/pathogens & Natural predators, parasites and pathogens may limit the abundance of snails & [23] \\
\hline Species & Variation of susceptibility to parasite and efficiency to produce cercariae & {$[27,32]$} \\
\hline Human-related factors & Effect on schistosomiasis transmission & Reference(s) \\
\hline Water contact behaviour & Exposure of the skin to parasite infested water is the prerequisite for human infection & [33] \\
\hline Hygiene & Contamination of water due to excrements of infected humans in or aside water & {$[20,34,35]$} \\
\hline Gender & $\begin{array}{l}\text { Relationship between gender and risk of infection is culturally variable and a determinant of } \\
\text { water contact activities }\end{array}$ & {$[35-37]$} \\
\hline Age & Highest risk for children as consequence of degree of exposure and low level of immunity & {$[33,35,38]$} \\
\hline Immunity & $\begin{array}{l}\text { Resistance to reinfection can be developed by the human body as a consequence of } \\
\text { previous infections }\end{array}$ & [38] \\
\hline Ethnic origin & Variation in the susceptibility to infection & [20] \\
\hline Religion & Religious rules related to water contact related to disease exposure & {$[20,35]$} \\
\hline Socioeconomic status & $\begin{array}{l}\text { Relation to hygiene, the availability of protected water supplies and ability to cope with the } \\
\text { disease }\end{array}$ & [39] \\
\hline Migration & $\begin{array}{l}\text { Population movements can modify spatial patterns of disease transmission through both } \\
\text { introduction of the parasite or the acquisition of infection }\end{array}$ & {$[20,33,40]$} \\
\hline Occupation & Work related to water increases the exposure and risk of infection (fishermen, farmers, etc.) & {$[34,35]$} \\
\hline Location of house & $\begin{array}{l}\text { Location of house in relation to suitability of closest water source can influence infection } \\
\text { status }\end{array}$ & {$[35,41,42]$} \\
\hline Prevention/control measures & $\begin{array}{l}\text { Spatial pattern of disease transmission can be highly modified by mass treatment campaigns } \\
\text { and successful preventive measures }\end{array}$ & {$[43-45]$} \\
\hline
\end{tabular}

been shown that snails are highly dispersed along streams and irrigation schemes [51], which can result in the agglomeration of snails and parasites in downstream areas, especially during and after rains occurred. Based on the assumption that higher stream order (in the hierarchical network of topographically induced water drainage) is linked to decreased flow velocity, a positive association between stream order and S. mansoni infection prevalence in 
school-aged children has been observed in the Man region of western Côte d'Ivoire [52].

Vegetation determines habitat suitability of freshwater snails in several ways. First, the presence of aquatic vegetation is positively linked to the amount of dissolved oxygen and the consumption of carbon dioxide $\left(\mathrm{CO}_{2}\right)$ and thereby linked to movement and reproduction of pulmonate snails [23]. Secondly, snails seek broad-leafed vegetation as surface to crawl on and deposit their egg masses, whereas the periphyton, which encrusts the submerged parts of the plant, provides the food supply for snails [23].

The nature of substratum of a water body is related to snail abundance. Firm mud rich in decaying organic matter provides a favourable habitat for snails. In contrast, clean sand, semi-liquid mud or a bottom with low organic matter does not provide a suitable snail habitat [30,34].

Water depth is related to the distribution of freshwater snails, which are generally found in shallow water near the margins of their habitats as a function of food, shelter and light conditions [29,53]. Snails are rarely found at depth in excess of 1.5-2 m. However, they are able to survive at a depth of up to $10 \mathrm{~m}$, but there is little risk of transmission of schistosomiasis whenever snails are at such high depths [29].

Sudden fluctuations of water levels, such as irrigation channels operated by pump schemes, provide habitats of low suitability to establish a snail population [23]. Importantly though, snail populations are able to persist in temporary habitats through their ability to aestivate during periods of drought in sheltered spots, under vegetation, on mud or in mud crevices [23,24]. In general, compared to Biomphalaria, Bulinus are more successful to withstand periods of prolonged desiccation, surviving up to one year by burying themselves beneath the substratum [24]. During this time, development of the parasite and cercarial shedding may be suspended temporarily [54].

Rainfall modifies snail habitat conditions in manifold ways. Heavy rainfall may sweep away snail populations due to high flow velocity [24,27]. Furthermore, temporary habitats are created by enduring rainfall events and snails can establish a population either if they survived desiccation or by being passively transported to a temporary habitat with the discharge of the rain. Another relevant aspect with respect to the probability of disease transmission is that rainfall directly supports the contamination of water through washing human excreta charged with Schistosoma eggs into potential snail habitats [20].

Water turbidity due to a high content of suspended minerals $(360 \mathrm{mg} / \mathrm{l})$ can impact the reproduction cycle of freshwater snails through smothering egg masses preventing development and hatching of eggs. However, adult snails do not seem to be affected [23,30]. Growth of aquatic plants is limited due to high turbidity and thereby habitat conditions become less favourable [23].

With regard to water chemistry and quality, a low $\mathrm{pH}$ may be directly harmful to snails [27]. Indeed, the frequency of snails was found to be associated with water hardness with a preference of snails for very hard waters [23]. Maximum tolerated concentrations and lethal concentrations of certain ions for snail species have been quantified by Deschiens [31]. In general, Bulinus show a greater tolerance to changing chemical conditions than Biomphalaria. However, the latter genus was found to have higher tolerance to chloride $\left(\mathrm{Cl}^{-}\right)$and sodium $\left(\mathrm{Na}^{+}\right)$ concentrations than Bulinus [23,31]. Industrially polluted waters were found to be unsuitable for intermediate host snails, whereas high snail abundance was found near human habitations, perhaps explained by waters polluted by human excreta that contain Schistosoma eggs [23].

Similar to the stimulation of cercarial shedding with daylight, snails themselves were observed to be noticeably active in sunlight [23]. Egg masses of snails are often seen in direct sunlight and are apparently unaffected [23]. Furthermore, sunlight corresponds to the flourishing of aquatic weeds, the abundance of microflora and thereby a high content of dissolved oxygen rendering the water highly suitable for snails $[23,24]$. In contrast, completely shaded pools provide unsuitable habitat conditions for snail proliferation [23].

There are several vertebrate and invertebrate predators that influence the abundance of snails [23]. Parasites such as leeches or trematodes and pathogens such as fungi, viruses and bacteria may be pathogenic to snails [23]. However, both predators and pathogens would mainly limit the abundance of aquatic snails [23]. Finally, the respective snail species have differing genetic predispositions that result in an intraspecific variation of the susceptibility to the miracidium of a parasite as well as its efficiency to produce cercariae $[27,32]$.

\section{Humans as definitive hosts}

Humans are the definitive host for S. mansoni and S. haematobium. Cercariae penetrate the intact skin of the human, transform to schistosomula, enter the blood stream, develop, pair up and start producing eggs within approximately two weeks [2]. Adult schistosome worm pairs produce eggs over the entire course of their life and part of the eggs are excreted through faeces (S. mansoni) or urine (S. haematobium). Schistosomiasis is a disease of poverty [2,55]. In African countries south of the Sahara, poverty usually goes hand-in-hand with poor hygiene and housing, limited access to clean water and improved sanitation, subsistence farming and low educational level - all of them exacerbating the risk of acquiring schistosomiasis [55]. Furthermore, low socioeconomic status is intimitely connected with the lack of 
a household to cope with the disease, as preventive and curative measures are out of reach.

The contamination of surface waters and their surroundings with human excreta containing Schistosoma eggs is an important driver of schistosomiasis transmission that is governed by human behaviour [20]. The rate of infection has been observed to be significantly higher in people living in houses without a latrine and without access to piped water $[34,35,56,57]$. However, water contact behaviour is the major, decisive factor related to the risk of acquiring schistosomiasis. Even when the environmental setting provides most suitable conditions for the transmission of the disease, infection does not occur, if people do not get in contact with freshwater bodies. Major activities related to infection were identified to be lack of personal hygiene, swimming, washing clothes and children playing in water [33]. Less critical activities were the washing of objects, fetching water and crossing water bodies most likely due to the relative short duration of water contact and the relatively small surface areas of the human body exposed to infested water [33].

The relationship between gender and risk of infection is equivocal and varies with the cultural background of the people $[35,58,59]$. In some regions, higher prevalence of infection in females could be related to the fact that water-related activities were several-fold greater for women than men [36], whereas an opposite relationship was found when men dominated the activities with exposure to water [37]. School-aged children and adolescents are usually at highest risk of infection with peak prevalences found at around 10-15 years [33]. This characteristic age-prevalence curve is due to high exposure when fetching and playing in water at this age [35] and there might be partially acquired immunity to the disease at an older age [33]. However, especially preschoolaged children and their mothers are at considerable risk due to water contact, although only relatively few studies have been conducted to further our understanding of the epidemiology and schistosomiasis in preschool-aged children and to come forward with recommendations for treatment and control that are tailored to specific settings [60-65]. Of note, the higher the transmission, the earlier the peak of infection prevalence is observed. This phenomenon has been termed the 'peak shift' [66]. Interestingly though, a community-based study in Côte d'Ivoire revealed a second peak at old age ( $>50$ years) [67]. With regard to immunity, it has been shown that humans are able to develop defence mechanisms that modify the effects of exposure with increasing age [38]. Hence, this typical convex shape of the age-prevalence and age-intensity curves with respect to schistosomiasis is argued to be related to a slow acquisition of immunity to reinfection following a slow death of adult worms from early infections [33,38]. This is the basic argument that development of a schistosomiasis vaccine should be possible [68].

Furthermore, it has been observed that the acute stage of schistosomiasis was rarely found in indigenous populations, yet often in travellers to endemic areas [20]. Large water resource development projects attract migrant workers and their families to hot spots of disease transmission [20]. Semi-permanent or seasonal workers migrate to large agricultural projects for harvesting, often related to extensive irrigation schemes [33,69,70]. These people are at high risk of acquiring schistosomiasis if they enter endemic areas; however, they may (re-)introduce the parasite into controlled or non-endemic areas [20]. It has also been observed that after the construction of new rail and highway systems in West Africa, the spatial distribution of schistosomiasis changed, following these transportation routes [40]. Differences in the susceptibility to the disease with respect to ethnic origin of humans have been attributed to the immunological response influenced by different ancestral experiences with the infection [20].

Religion plays a role when respective rules govern practices that may significantly affect patterns of water use [35]. For example, ritual washing five times a day before prayer as required by male Muslims significantly affects the prevalence of Schistosoma infection in the respective communities [20].

A strong correlation between occupation and risk of infection is not surprising, particularly if work is related to water exposure [35]. For example, farmers and farm laborers, and especially fishermen and boatmen, showed higher Schistosoma prevalence rates than factory workers [34].

The location of a household in relation to the suitability of a water body to transmit the disease has shown to be highly relevant with respect to the level of prevalence [35]. Indeed, a study in Ghana found that high infection levels were clustered around ponds known to contain intermediate host snails of $S$. haematobium, whilst prevalence was low in households in close proximity to a river where the intermediate host snails were rarely found [41]. A study by Mota and Sleigh [42] concluded that the relative location of a house to snail-free or snail-colonised water sources was a key driver explaining the spatial pattern of S. mansoni infection in Brazil.

The use of control measures alters the prevalence and intensity of infection, and thus morbidity due to schistosomiasis, and might impact on disease transmission. Following mass treatment campaigns, the level of prevalence and morbidity decreased considerably [43,71]. However, numerous studies revealed that reinfection occurs rapidly whenever preventive measures have been neglected (see, for example $[44,45]$ ), thus not addressing the root social and ecological causes of schistosomiasis [72-75]. 


\section{Remote sensing of schistosomiasis}

The first application of remote sensing to predict the probability of occurrence of human schistosomiasis using Landsat 5 Thematic Mapper (TM) data was published in 1984 for the Philippines by Cross et al. [76]. Initially, the use of remote sensing data to estimate the impact of disease casualty rates was driven by military and economic interests and only later applied for epidemiological investigations [77].

A decade after the pioneering work by Cross and colleagues, diurnal temperature differences derived from data of the National Oceanic and Atmospheric AdministrationAdvanced Very High Resolution Radiometer (NOAAAVHRR) have been related to survey measurements of schistosomiasis prevalence in Egypt [78]. As thermal differences between day and night reflect regional hydrologic conditions [79], the significant inverse relationship showed well the predictive ability of remote sensing data for schistosomiasis transmission risk [78].

We were interested in more recent applications of remote sensing for schistosomiasis risk profiling. Hence, we determined the number of published studies by accessing the online library PubMed (http://www.ncbi. nlm.nih.gov/pubmed/). Our search was conducted in early February 2015 according to the terms and Boolean operators provided by the review of Simoonga et al. [11] covering the period between 1 January 1995 and 31 December 2014, complemented with a detailed focus on reviewing remote sensors, environmental variables, as well as temporal and geographical coverage of data (Table 3). Our PubMed search resulted in 93 publications, of which 31 were relevant reviews or case studies using remote sensing data for spatial modelling of schistosomiasis risk. Within the process of reviewing the literature and critically examining the cited references, the number of relevant studies increased to 37 .

The potential of remote sensing and its combination with geographical information system (GIS)-based spatial analyses for schistosomiasis risk profiling can be summarised by the ability (i) to determine the geographical limit of disease distribution due to ecological constraints of disease transmission; (ii) to further investigate the context of disease ecology and epidemiology through its spatial relation; (iii) to support prevention, surveillance and control through prioritising areas of disease risk; and (iv) to provide early warning for areas where disease transmission could become established $[4,9,11,80,109-112]$. However, most studies had an integrative focus combining some of the different analytical steps from spatial disease delineation to early warning mentioned above. The most frequently used remote sensing data are from the NOAA-AVHRR and later the Moderate Resolution Imaging Spectroradiometer (MODIS) with ground resolutions of $1.1 \mathrm{~km}$ and $250 \mathrm{~m}$, respectively.
Only few studies have used high resolution data from Landsat 5 TM $(30 \mathrm{~m})$ and very high resolution remote sensing data $(1 \mathrm{~m})$ have solely been investigated for one study site in Kenya $[41,51,108]$.

Topographic information from either Shuttle Radar Topography Mission (SRTM) data or the global digital elevation model with 30-arc second resolution (GTOPO30) were added in most studies as predictor variable. The environmental parameters most commonly used were the NDVI and land surface temperature (LST), hypothesised to represent surrogate measures of environmental moisture and temperature, respectively [82]. The availability of AVHRR and MODIS data free of charge and the online access to pre-processed imagery boosted studies that investigated these data [16]. However, as already stated by Herbreteau et al. [16], there are many other vegetation- [113] or moisture-related indices [114] not directly accessible due to their more complex nature, which are rarely used for health studies. Several studies (see, for example $[97,99,100]$ ) have used spatial information of perennial water bodies and river networks from the GeoNetwork platform provided by the Food and Agriculture Organization (FAO) of the United Nations [115]. However, the acquisition dates back to the 1990s and it lacks information on temporal dynamics. Availability of more recent data would be highly relevant to monitor environmental changes such as construction of dam lakes or irrigation schemes [1]. Satellite remote sensing provides data and methodological procedures to map and monitor water bodies and other disease relevant parameters such as water temperature, turbidity or vegetation coverage [12].

Reference data for the spatial analysis with remote sensing data were mostly point data, either of human infection prevalence most frequently geo-located at schools, or snail occurrence located in sampled water bodies (Table 3). Overall, snail data were very rarely available and most analyses were based on infection of school-aged children surveyed. In most studies, infection of school-aged children has been determined using parasitological examinations of stool and urine examination and microscopy, whilst only few studies were built upon prevalence data based on morbidity questionnaires (see, for example [96]). Epidemiological data of human infection or snail sampling often had a temporal mismatch of several years between the sampling and the acquisition of remote sensing data (see, for example [95,104]). However, this has been considered as negligible drawback, since schistosomiasis is a chronic disease with a life-span of adult worms being typically several years in the absence of treatment interventions [20]. Therefore, spatial variability in long-term synoptic environmental factors is hypothesised to have more influence on transmission success and infection patterns than seasonal variability 
Table 3 Overview of remote sensing data and derived environmental variables investigated for spatial analyses of schistosomiasis from 1 January 1995 to 31

\section{December 2014}

\begin{tabular}{|c|c|c|c|c|c|c|c|}
\hline \multirow[t]{2}{*}{ Satellite sensor } & \multirow{2}{*}{$\begin{array}{l}\text { Environmental } \\
\text { variable }\end{array}$} & \multirow{2}{*}{$\begin{array}{l}\text { Sensor } \\
\text { combination }\end{array}$} & \multirow[t]{2}{*}{ Geographic area } & \multirow[t]{2}{*}{ Temporal coverage } & \multicolumn{2}{|l|}{ Reference data } & \multirow[t]{2}{*}{ Reference(s) $^{*}$} \\
\hline & & & & & Snail & Human infection & \\
\hline \multirow[t]{20}{*}{$\begin{array}{l}\text { NOAA-AVHRR } \\
\text { spatial resolution: } \\
1.1 \mathrm{~km}\end{array}$} & $\begin{array}{l}\text { Diurnal temperature } \\
\text { difference NDVI }\end{array}$ & Landsat & Egypt & $\begin{array}{l}\text { Monthly time series } \\
\text { 1990-1991 }\end{array}$ & $\begin{array}{l}\text { Snail occurrence, } \\
\text { infection rate } \\
\text { (water survey } \\
1 \text { km distance to } \\
\text { population } \\
\text { survey) }\end{array}$ & Survey prevalence (rural health units) & [80] \\
\hline & LST, NDVI & SRTM & Tanzania & $\begin{array}{l}\text { Monthly time series } \\
\text { 1985-1998 }\end{array}$ & & Survey prevalence (school) & [81] \\
\hline & LST, NDVI & & Ethiopia - East Africa & $\begin{array}{l}\text { Annual + seasonal } \\
\text { composites 1992-1996 }\end{array}$ & & Survey prevalence (town/village) - $5 \mathrm{~km}$ buffer & [82] \\
\hline & LST, NDVI & & Ethiopia & $\begin{array}{l}\text { Annual + seasonal } \\
\text { composites 1992-1996 }\end{array}$ & Snail occurrence & Survey prevalence (town/village) - $5 \mathrm{~km}$ buffer & [83] \\
\hline & LST, NDVI & & Cameroon & 1985-1998 & & $\begin{array}{l}\text { Survey prevalence (district - stratified at school } \\
\text { level) }\end{array}$ & [84] \\
\hline & LST, NDVI & Landsat GTOPO30 & Uganda & Not indicated & & $\begin{array}{l}\text { Survey prevalence, infection intensity } \\
\text { (school/village) }\end{array}$ & [85] \\
\hline & LST, NDVI & & $\begin{array}{l}\text { Kenya, Ethiopia, } \\
\text { Uganda }\end{array}$ & $\begin{array}{l}\text { Annual + seasonal } \\
\text { composites 1992-1995 }\end{array}$ & Snail occurrence & CEGET/WHO atlas - $5 \mathrm{~km}$ buffer & [86] \\
\hline & Land cover & $\begin{array}{l}\text { MODIS, Landsat, } \\
\text { METEOSAT, } \\
\text { GTOPO30 }\end{array}$ & Côte d'Ivoire & 1992/1993 & & Survey prevalence (school) & {$[87,88]$} \\
\hline & LST, NDVI & GTOPO30 & Tanzania & 1982-1998 & & Survey prevalence (school) & [89] \\
\hline & LST, NDVI & GTOPO30 & East Africa & $1982-2000$ & & Survey prevalence (school) & [90] \\
\hline & Land cover & GTOPO30 & Côte d'Ivoire & 1992/1993 & & Survey prevalence (school) & [91] \\
\hline & LST, NDVI & & $\begin{array}{l}\text { Burkina Faso, Mali, } \\
\text { Niger }\end{array}$ & Not indicated & & Survey prevalence (school) & [92] \\
\hline & LST, NDVI & & Nigeria & $2001-2002$ & & Survey prevalence (school) & [93] \\
\hline & LST, NDVI & & Zambia & 1992-1995 & $\begin{array}{l}\text { Snail occurrence, } \\
\text { cercarial } \\
\text { shedding }\end{array}$ & $\begin{array}{l}\text { Survey prevalence, infection intensity } \\
\text { (school/village) }\end{array}$ & [94] \\
\hline & LST, NDVI & & East Africa & $1982-2000$ & & Survey prevalence (school) & [95] \\
\hline & LST, NDVI & & Tanzania & Not indicated & & Survey prevalence (school) & [96] \\
\hline & LST, NDVI & & Burkina Faso, Mali & 1982-1998 & & Survey prevalence (school) & [97] \\
\hline & NDVI & & Sudan & Not indicated & & Survey prevalence (village) & [98] \\
\hline & LST, NDVI & SRTM & Sierra Leone & Not indicated & & Survey prevalence (school) & {$[99,100]$} \\
\hline & LST, NDVI & & Ghana & Not indicated & & Survey prevalence (school) & [101] \\
\hline
\end{tabular}


Table 3 Overview of remote sensing data and derived environmental variables investigated for spatial analyses of schistosomiasis from 1 January 1995 to 31 December 2014 (Continued)

\begin{tabular}{|c|c|c|c|c|c|c|c|}
\hline \multirow[t]{6}{*}{$\begin{array}{l}\text { MODIS } \\
\text { spatial resolution: } \\
1 \text { km, } 500 \text { m, } 250 \mathrm{~m}\end{array}$} & LST, NDVI & $\begin{array}{l}\text { NOAA-AVHRR, } \\
\text { Landsat, } \\
\text { METEOSAT, } \\
\text { GTOPO30 }\end{array}$ & Côte d'Ivoire & $\begin{array}{l}\text { Monthly time series } \\
\text { January + November } \\
2002\end{array}$ & & Survey prevalence (school) & {$[87,88]$} \\
\hline & LST, NDVI & & Uganda & $\begin{array}{l}\text { Annual + seasonal } \\
\text { composites 2000-2003 }\end{array}$ & Snail occurrence & Survey prevalence (school) & [102] \\
\hline & LST, NDVI & & Uganda & $\begin{array}{l}\text { Annual + seasonal } \\
\text { composites 2000-2003 }\end{array}$ & Snail occurrence & Survey prevalence (school) & [103] \\
\hline & LST, NDVI, Land cover & GTOPO30 & West Africa & $2000-2008$ & & Survey prevalence (school) & {$[104]$} \\
\hline & LST, NDVI Land cover & GTOPO30 & East Africa & 2000-2009 & & Survey prevalence (school/community) & {$[105,106]$} \\
\hline & LST, NDVI & METEOSAT, SRTM & Côte d'Ivoire & Not indicated & & Survey prevalence (school) & [107] \\
\hline \multirow[t]{4}{*}{$\begin{array}{l}\text { Landsat TM/ETM + } \\
\text { spatial resolution: } \\
30 \mathrm{~m}, 60 \mathrm{~m}\end{array}$} & $\begin{array}{l}\text { Spectral bands: } \\
\text { (blue(1), red(3), } \\
\text { mir(5), thermal(6)) } \\
\text { NDVI Tasseled cap: } \\
\text { brightness, } \\
\text { greenness, wetness }\end{array}$ & NOAA-AVHRR & Egypt & May 1990 & $\begin{array}{l}\text { Number, } \\
\text { distribution, } \\
\text { infection rate }\end{array}$ & Survey prevalence (rural health units) & [80] \\
\hline & Water body map & $\begin{array}{l}\text { NOAA-AVHRR, } \\
\text { GTOPO30 }\end{array}$ & Uganda & March 2000 & & $\begin{array}{l}\text { Survey prevalence, infection intensity } \\
\text { (school/village) }\end{array}$ & {$[85]$} \\
\hline & $\begin{array}{l}\text { Settlements, roads, } \\
\text { rivers }\end{array}$ & $\begin{array}{l}\text { NOAA-AVHRR, } \\
\text { MODIS, } \\
\text { METEOSAT, } \\
\text { GTOPO30 }\end{array}$ & Côte d'Ivoire & $\begin{array}{l}\text { January + November } \\
2002\end{array}$ & & Survey prevalence (school) & {$[87,88]$} \\
\hline & $\begin{array}{l}\text { NDMSI (normalized } \\
\text { difference moisture } \\
\text { stress index) }\end{array}$ & Ikonos, SRTM & Kenya & $\begin{array}{l}\text { June } 1986+\text { January } \\
2003\end{array}$ & $\begin{array}{l}\text { Snail/shell } \\
\text { occurrence }\end{array}$ & & [51] \\
\hline $\begin{array}{l}\text { Ikonos } \\
\text { spatial resolution: } \\
1 \mathrm{~m}\end{array}$ & Land cover & Landsat, SRTM & Kenya & March & $\begin{array}{l}\text { Snail/shell } \\
\text { occurrence }\end{array}$ & & {$[41,51,108]$} \\
\hline \multirow[t]{2}{*}{$\begin{array}{l}\text { METEOSAT } \\
\text { spatial resolution: } \\
8 \mathrm{~km}\end{array}$} & Rainfall estimates & $\begin{array}{l}\text { NOAA-AVHRR, } \\
\text { MODIS, Landsat, } \\
\text { GTOPO30 }\end{array}$ & Côte d'Ivoire & $\begin{array}{l}\text { September } \\
\text { 2001-August } 2002\end{array}$ & & Survey prevalence (school) & {$[87,88]$} \\
\hline & Rainfall estimates & MODIS, SRTM & Côte d'Ivoire & Not indicated & & Survey prevalence (school) & [107] \\
\hline \multirow{2}{*}{$\begin{array}{l}\text { SRTM } \\
\text { spatial resolution: } \\
90 \mathrm{~m}\end{array}$} & Altitude & NOAA-AVHRR & Tanzania & February 2000 & & Survey prevalence (school) & [81] \\
\hline & $\begin{array}{l}\text { Altitude, slope, } \\
\text { stream order, } \\
\text { catchment }\end{array}$ & & Côte d'Ivoire & February 2000 & & Survey prevalence (school) & {$[52,107]$} \\
\hline
\end{tabular}


Table 3 Overview of remote sensing data and derived environmental variables investigated for spatial analyses of schistosomiasis from 1 January 1995 to 31 December 2014 (Continued)

\begin{tabular}{|c|c|c|c|c|c|c|c|}
\hline & $\begin{array}{l}\text { Altitude, slope, } \\
\text { drainage network }\end{array}$ & Landsat, Ikonos & Kenya & February 2000 & $\begin{array}{l}\text { Snail/shell } \\
\text { occurrence }\end{array}$ & & [51] \\
\hline & Altitude & NOAA-AVHRR & Sierra Leone & February 2000 & & Survey prevalence (school) & [99] \\
\hline \multirow{7}{*}{$\begin{array}{l}\text { GTOPO30 } \\
\text { spatial resolution: } \\
30 \text { sec (ca. } 1 \text { km) }\end{array}$} & Altitude & $\begin{array}{l}\text { NOAA-AVHRR, } \\
\text { Landsat }\end{array}$ & Uganda & 1994-1997 & & $\begin{array}{l}\text { Survey prevalence, Infection intensity } \\
\text { (school/village) }\end{array}$ & {$[85]$} \\
\hline & Altitude & $\begin{array}{l}\text { NOAA-AVHRR, } \\
\text { MODIS, } \\
\text { METEOSAT, } \\
\text { Landsat }\end{array}$ & Côte d'Ivoire & 1994-1997 & & & {$[87,88]$} \\
\hline & Altitude & NOAA-AVHRR & Tanzania & 1994-1997 & & Survey prevalence (school) & [89] \\
\hline & Altitude & NOAA-AVHRR & East Africa & 1994-1997 & & Survey prevalence (school) & [90] \\
\hline & Altitude & NOAA-AVHRR & East Africa & 1994-1997 & & Survey prevalence (school) & [91] \\
\hline & Altitude & MODIS & Côte d'Ivoire & 1994-1997 & & Survey prevalence (school) & [104] \\
\hline & Altitude & MODIS & East Africa & 1994-1997 & & Survey prevalence (school/community) & [106] \\
\hline
\end{tabular}


in a location [95]. When environmental variables such as NDVI or LST are used to predict the risk of schistosomiasis, "in effect, one is predicting the environmental requirements for a particular snail species (infected with a particular parasite species) - and not the human parasitic infection per se" [11]. An analysis of remote sensing data with respect to snail abundance and disease prevalence showed that snail distribution generally corresponded to the prediction model of schistosomiasis prevalence, however, the best model of snail distribution showed different ranges of temperature than found in schistosomiasis prevalence models $[82,83]$. One remaining challenge to further improve remote sensing and GISbased risk profiling is to account for the spatial mismatch between the school-based measurement of human infection and the water body, where disease transmission occurs and remote sensing variables have the potential to provide ecologically relevant measurements to characterise habitat conditions of disease-related parasites and intermediate host snails.

Environmental analyses using remote sensing data provide the opportunity for a deeper understanding of the process underlying broad-scale patterns of schistosomiasis distribution and can help to potentially improve our knowledge of schistosomiasis infection ecology [9]. To give an example, a study by Raso et al. [87] found that - besides age, sex and socioeconomic status - rainfall pattern and elevation significantly explained the geographical variation of $S$. mansoni distribution in the mountainous Man region, western Côte d'Ivoire. For the same region, Beck-Wörner et al. [52] found a significant correlation for stream order of the closest river, the water catchment and altitude. However, the observed significant relationship between Schistosoma prevalence among school-aged schildren and elevation was not apparent in a risk model for sub-continental West Africa [97]. For sub-continental East Africa, a negative correlation resulted from the distance to freshwater body and elevation with respect to the distribution of $S$. mansoni infection intensity [90]. This shows that predictor variables and resulting models are specific to the reference data, the scale of observation and the geography of the study site. A reasonable impact of different ecological zones on predictor performance and model outcome was first established by Brooker et al. [81] in Tanzania, a phenomenon that should be kept in mind when using remote sensing data for modelling disease risk.

Remote sensing and GIS have proven to be useful for planning and implementing disease intervention and control programmes by excluding areas where schistosomiasis is unlikely to be a public health problem and modelling priority areas of increased transmission risk $[9,81]$. Clements et al. [92] predicted regions with a probability of Schistosoma infection in the school-aged population greater than 50\% in Burkina Faso, Mali and Niger, which calls for mass treatment campaigns according to guidelines put forth by the World Health Organization (WHO) [116]. Estimates of the number of school-aged children who are at particularly high risk have been predicted for West Africa [104] and East Africa [105], and for two countries; namely Tanzania [81] and Nigeria [117]. Additionally, expectable programme costs emphasising large-scale treatment administration were calculated based on model predictions. Estimated treatment costs were higher if data were aggregated on a provincial level compared to the national level, which might be explained by large spatial heterogeneities of disease risk at the sub-national level. This indicates that the issue of scale must be considered in spatially explicit risk profiling [118].

Many studies focused on modelling the risk of polyparasitic helminth infections, such as $S$. mansoni and soil-transmitted helminths, with the objective to enhance cost-effectiveness of integrated control approaches (see, for example, $[88,100,119])$. Mass treatment campaigns, however, often lack sustainability, because specific freshwater bodies might act as high transmission zones if they are (re-)contaminated by even a single untreated individual. This consideration suggests the importance of water-site factors to achieve a shift from morbidity to transmission control and local elimination [120-122]. In this regard, remote sensing data hold promise to monitor the presence and dynamics of water-sites and further characteristics such as water surface temperature and other environmental variables.

\section{Linkage between remote sensing and disease ecology in space}

The review of risk factors that influence schistosomiasis transmission ecology (see Table 2) and previous applications of remote sensing data for schistosomiasis risk profiling (see Table 3) were further synthesised and condensed and are presented in Table 4. This overview is structured according to the steps of the parasite life cycle and (i) shows the potential contribution of remote sensing data for schistosomiasis risk profiling and (ii) indicates the meaning of remote sensing measurements with respect to the ecological relevance for disease transmission. In the context of modelling schistosomiasis risk, remote sensing variables can provide either direct measurements of the feature of interest, which are, for example, the measure of LST, water persistence or flow velocity or vegetation coverage along water sites. These variables are derived from respective remote sensing metrics such as land surface emissivity or surface reflectance at appropriate wavelengths according to their spectral properties. They can directly reflect habitat conditions and provide information about the potential impact on the ecology 
Table 4 Synthesis of remote sensing contribution for schistosomiasis risk profiling

\begin{tabular}{|c|c|c|c|}
\hline & Factor impacting on disease transmission & Remote sensing (proxy) variable & Ecological impact \\
\hline \multirow[t]{7}{*}{ Parasite } & Water body & Near and middle infrared reflectance & Hatching of eggs; infection of snail and human host \\
\hline & Water temperature & Thermal infrared (emissivity) & $\begin{array}{l}\text { Length of prepatent period; activity, survival and } \\
\text { infection rate }\end{array}$ \\
\hline & Water flow velocity & Topography: slope angle, curvature & $\begin{array}{l}\text { Determination of maximal cercarial density; passive } \\
\text { transport of parasite }\end{array}$ \\
\hline & Predators & NA & Reduction of parasite population \\
\hline & Sunlight & Shaded habitats (tree coverage) & Reduction of parasite population \\
\hline & Pathogenicity & NA & Severity of disease in humans \\
\hline & Species & NA & Different efficiency of snail infection \\
\hline \multirow[t]{13}{*}{ Snail } & Water body & Near and middle infrared reflectance & $\begin{array}{l}\text { Fundamental habitat of snail to maintain a } \\
\text { population }\end{array}$ \\
\hline & Water temperature & Thermal infrared (emissivity) & Fecundity, mortality and rate of reproduction \\
\hline & Water flow velocity & Topography: slope angle, curvature & $\begin{array}{l}\text { Determination of snail density; passive transport of } \\
\text { snail; food availability }\end{array}$ \\
\hline & Vegetation & Visible and near infrared reflectance & $\begin{array}{l}\text { Food supply; surface for oviposition; increase of } \\
\text { dissolved oxygen }\end{array}$ \\
\hline & Substratum & NA & Abundance of snails in water body \\
\hline & Water depth & Visible and near infrared reflectance & Abundance of snails in water body \\
\hline & Stability of water level & Temporal dynamic of water body & Abundance of snails in water body \\
\hline & Rainfall & Cloud thickness and temperature & $\begin{array}{l}\text { Creation of temporary snail habitats; modification of } \\
\text { water flow velocity; supports contamination of water }\end{array}$ \\
\hline & Turbidity & Visible and near infrared reflectance & Reproduction cycle of snails \\
\hline & Water chemistry/quality & NA & Abundance of snails in water body \\
\hline & Sunlight & Shaded habitats (tree coverage) & Abundance and activity of snails \\
\hline & Predators, parasites and pathogens & NA & Reduction of snail population \\
\hline & Species & NA & Susceptibility to parasite and cercarial productivity \\
\hline \multirow[t]{11}{*}{ Human } & Water contact behaviour & NA & $\begin{array}{l}\text { Exposure to parasite infested water; contamination } \\
\text { of surface waters }\end{array}$ \\
\hline & Gender & NA & $\begin{array}{l}\text { Determinant of water contact activities (culturally } \\
\text { variable) }\end{array}$ \\
\hline & Age & NA & $\begin{array}{l}\text { Related to degree of exposure and level of } \\
\text { immunity }\end{array}$ \\
\hline & Immunity & NA & $\begin{array}{l}\text { Resistance to reinfection can be developed } \\
\text { following previous infections }\end{array}$ \\
\hline & Ethnic origin & NA & Susceptibility to infection \\
\hline & Religion & NA & Religious practices may affect patterns of water use \\
\hline & Socioeconomic status & NA & $\begin{array}{l}\text { Standard of hygiene; access to protected water } \\
\text { supply; ability to cope with disease }\end{array}$ \\
\hline & Migration & NA & Modification of spatial distribution of disease \\
\hline & Occupation & NA & Work related to water increases exposure \\
\hline & Location of the house & Settlement mapping & $\begin{array}{l}\text { Exposure of population to potential disease } \\
\text { transmission sites }\end{array}$ \\
\hline & Prevention/control measures & NA & $\begin{array}{l}\text { Modification of spatial pattern of disease } \\
\text { transmission }\end{array}$ \\
\hline
\end{tabular}

of disease transmission. On the other hand, remote sensing data provide proxy variables, where the remotely sensed measurement is not representing the respective measure influencing disease transmission but being indirectly linked to the requested information.
For example, based on remote sensing data, the slope of a land surface can be measured from topographical modelling, however, the relevant information to be drawn from this proxy measure would be water flow velocity as the decisive criterion for profiling risk of 
disease transmission. Due to an additional step of modelling information to ecological indicators, the potential sources of errors that affect the data may increase.

Table 4 illustrates that there are risk factors governing schistosomiasis transmission that can potentially be measured by remote sensing data and others that cannot. Specifically, parasite- and snail-related risk factors are well addressed by remote sensing measurements. However, it shows also very clearly that remote sensing has its natural limitations and cannot detect factors such as intrinsic factors related to parasites, snails and humans as well as some chemical and biological aspects. Thus, remotely sensed environmental measurements can contribute substantially to characterise the habitat conditions of parasites and snails and can moreover detect human settlements and their spatial relation to suitable habitat conditions. However, against this background, it has to be kept in mind that remote sensing-based approaches for disease risk profiling have gaps of information to be filled by other disciplines.

\section{Review; conclusion}

In our view, the issue of schistosomiasis risk profiling has not been addressed with sufficient depth by interdisciplinary groups of epidemiologists and remote sensors. In this review, we made an attempt to bridge the two strands of scientific inquiry, based on specific professional expertises and experience. Taking up this task, the present work has synthesised an informed linkage between remote sensing measurements of surface conditions and ecological processes that govern the transmission of schistosomiasis. Our synthesis deepens the understanding of this interdisciplinary linkage and thereby allows quantification of remote sensing contribution for overall disease risk estimation. Our review suggests that the potential of remote sensing data for schistosomiasis risk profiling is greater than explored to date. Indeed, there is a multitude of remote sensing data and variables other than NDVI and LST available that need to be investigated to specifically address ecological conditions relevant for schistosomiasis transmission. Freely available remote sensing data sources to achieve these investigations are for example the newest Landsat 8 pre-processed data products (see, http://landsat.usgs.gov/CDR_ECV.php) with spatial resolution of $30 \mathrm{~m}$, or $20 \mathrm{~m}$ data from the Sentinel 2 mission (http://www.esa.int/Our_Activities/ Observing_the_Earth/Copernicus/Sentinel-2), which is scheduled to be launched in May 2015. Our review also emphasises that the scale of observation, geographical area and variables used impact the outcome of schistosomiasis risk models, and hence demands for a tailored approach. One remaining challenge to further improve remote sensing and GIS-based risk mapping and prediction is to account for the spatial mismatch between remote sensing measurements of potential schistosomiasis-related parasite and snail habitats and school- or community-based measurements of human infection, which has not been considered in any of the reviewed studies. Especially with regard to the unfolding agenda of elimination of schistosomiasis and other helminthiases [122-124], thus going beyond morbidity control, sites where schistosomiasis transmission potentially occurs need to be specifically addressed. A better integration of remote sensing data in epidemiology holds promise to detect and characterise potential disease transmission sites and thereby support new integrated prevention and control strategies to combat schistosomiasis.

\section{Abbreviations}

DALY: Disability-adjusted life year; FAO: Food and Agriculture Organization; GIS: Geographical information system; GTOPO30: Global digital elevation model with 30-arc second resolution; LST: Land surface temperature; MODIS: Moderate-Resolution Imaging Spectroradiometer; NDVI: Normalized difference vegetation index; NOAA-AVHRR: National Oceanic and Atmospheric Administration-Advanced Very High Resolution Radiometer; SRTM: Shuttle Radar Topography Mission; WHO: World Health Organization.

\section{Competing interests}

The authors declare that they have no competing interests.

\section{Authors' contributions}

YW, MW, SD, GR and JU participated in the design of the study. YW conducted the literature review and drafted the manuscript jointly with MW and JU. GR and JU helped interpreting the review results and revised the manuscript. All authors read and approved the manuscript prior to submission.

\section{Acknowledgements}

YW is grateful for financial support of the German Aerospace Centre (DLR) and a scholarship received from the "Equal Opportunities for Women in Research and Training" programme at the University of Würzburg.

\section{Author details}

'Department of Remote Sensing, Institute for Geography and Geology, University of Würzburg, Würzburg, Germany. ${ }^{2}$ United Nations University Institute for Environment and Human Security, Bonn, Germany. ${ }^{3}$ German Remote Sensing Data Centre, German Aerospace Centre, Oberpfaffenhofen, Germany. ${ }^{4}$ Department of Epidemiology and Public Health, Swiss Tropical and Public Health Institute, Basel, Switzerland. ${ }^{5}$ University of Basel, Basel, Switzerland.

Received: 6 November 2014 Accepted: 12 February 2015

Published online: 17 March 2015

\section{References}

1. Steinmann P, Keiser J, Bos R, Tanner M, Utzinger J. Schistosomiasis and water resources development: systematic review, meta-analysis, and estimates of people at risk. Lancet Infect Dis. 2006;6:411-25.

2. Colley DG, Bustinduy AL, Secor WE, King CH. Human schistosomiasis. Lancet. 2014;383:2253-64

3. Murray CJL, Vos T, Lozano R, Naghavi M, Flaxman AD, Michaud C, et al. Disability-adjusted life years (DALYs) for 291 diseases and injuries in 21 regions, 1990-2010: a systematic analysis for the Global Burden of Disease Study 2010. Lancet. 2012;380:2197-223.

4. Malone JB. Biology-based mapping of vector-borne parasites by geographic information systems and remote sensing. Parassitologia. 2005:47:27-50.

5. Kalluri S, Gilruth P, Rogers D, Szczur M. Surveillance of arthropod vector-borne infectious diseases using remote sensing techniques: a review. PLoS Pathog. 2007;3:e116. 
6. Hay SI, Packer MJ, Rogers DJ. The impact of remote sensing on the study and control of invertebrate intermediate hosts and vectors for disease. Int J Remote Sens. 1997;18:2899-930.

7. Beck LR, Lobitz BM, Wood BL. Remote sensing and human health: new sensors and new opportunities. Emerg Infect Dis. 2000;6:217-26.

8. Hay SI, Randolph SE, Rogers DJ. Remote sensing and geographical information systems in epidemiology - guest editors' preface. Adv Parasitol. 2000;47:xi-xii.

9. Brooker S. Schistosomes, snails and satellites. Acta Trop. 2002;82:207-14.

10. Yang GJ, Vounatsou P, Zhou XN, Utzinger J, Tanner M. A review of geographic information system and remote sensing with applications to the epidemiology and control of schistosomiasis in China. Acta Trop. 2005;96:117-29.

11. Simoonga C, Utzinger J, Brooker S, Vounatsou P, Appleton CC, Stensgaard AS, et al. Remote sensing, geographical information system and spatial analysis for schistosomiasis epidemiology and ecology in Africa. Parasitology. 2009;136:1683-93.

12. Tran A, Goutard F, Chamaillé L, Baghdadi N, Lo Seen D. Remote sensing and avian influenza: a review of image processing methods for extracting key variables affecting avian influenza virus survival in water from Earth observation satellites. Int J Appl Earth Obs Geoinf. 2010;12:1-8.

13. Rinaldi L, Musella V, Biggeri A, Cringoli G. New insights into the application of geographical information systems and remote sensing in veterinary parasitology. Geospat Health. 2006;1:33-47.

14. IEA (International Epidemiological Association). A Dictionary of Epidemiology. 3rd ed. New York, Oxford, Toronto: Oxford University Press; 1995.

15. Kearney M. Habitat, environment and niche: what are we modelling? Oikos. 2006:115:186-91.

16. Herbreteau V, Salem G, Souris M, Hugot JP, Gonzalez JP. Thirty years of use and improvement of remote sensing, applied to epidemiology: from early promises to lasting frustration. Health Place. 2007;13:400-3.

17. King $\mathrm{CH}$. Toward the elimination of schistosomiasis. N Engl J Med. 2009;360:106-9.

18. Pflüger W. Experimental epidemiology of schistosomiasis. I. The prepatent period and cercarial production of Schistosoma mansoni in Biomphalaria snails at various constant temperatures. Z Parasitenkd. 1980;63:159-69.

19. Sturrock RF. The parasites and their life cycle. In: Jordan P, Webbe G, Sturrock RF, editors. Human schistosomiasis. Wallingford: CAB International; 1993. p. 1-32.

20. Jordan P, Webbe G. Epidemiology. In: Jordan P, Webbe G, Sturrock RF, editors. Human schistosomiasis. Wallingford: CAB International; 1993. p. 87-152.

21. Gibson M, Warren KS. Capture of Schistosoma mansoni miracidia and cercariae by carnivorous aquatic vascular plants of the genus Utricularia. Bull World Health Organ. 1970;42:833-5.

22. Stirewalt MA. Important features of the schistosomes. In: Ansari N, editor. Epidemiology and control of schistosomiasis (bilharziasis). Basel and Baltimore: S. Karger and University Park Press; 1973. p. 17-31.

23. Abdel-Malek E. Factors conditioning the habitat of bilharziasis intermediate hosts of the family Planorbidae. Bull World Health Organ. 1958;18:785-818.

24. Appleton CC. Review of the literature on abiotic factors influencing the distribution and life-cycles of bilharziasis intermediate host snails. Malacol Rev. 1978;11:1-25.

25. Shiff CJ. Studies on Bulinus (Physopsis) globosus in Rhodesia. I The influence of temperature on the intrinsic rate of natural increase. Ann Trop Med Parasitol. 1964;58:94-105.

26. Shiff CJ, Garnett B. The influence of temperature on the intrinsic rate of natural increase of the freshwater snail B. pfeifferi. Arch Hydrobiol. 1967;62:429-38.

27. Sturrock RF. The intermediate hosts and host-parasite relationships. In: Jordan P, Webbe G, Sturrock RF, editors. Human schistosomiasis. Wallingford: CAB International; 1993. p. 33-85.

28. Scorza JV, Silva J, Gonzalez L, Machado R. Stream velocity as a gradient in Australorbis glabratus (Say, 1818). Z Tropenmed Parasitol. 1961;12:191-6.

29. WHO. Study group on the ecology of intermediate snail hosts of bilharziasis. WHO Tech Rep Ser. 1957;120:1-40.

30. Harrison AD, Farina TDW. A naturally turbid water with deleterious effects on egg capsules of planorbid snails. Ann Trop Med Parasitol. 1965;59:327-30

31. Deschiens $R$. Incidence de la minéralisation de l'eau sur les mollusques vecteurs des bilharzioses. Consequences pratiques. Bull Soc Pathol Exot 1954;47:915-29.
32. Mulvey M, Vrijenhoek RC. Population structure in Biomphalaria glabrata examination of an hypothesis for the patchy distribution of susceptibility to schistosomes. Am J Trop Med Hyg. 1982;31:1195-200.

33. Bundy DAP, Blumenthal U. Human behaviour and the epidemiology of helminth infection. In: Barnard C, Behnke JM, editors. Parasitism and host behaviour. London: Taylor and Francis; 1990. p. 264-89.

34. Farooq M, Nielsen J, Samaan SA, Mallah MB, Allam AA. The epidemiology of Schistosoma haematobium and S. mansoni infections in the Egypt-49 project area. 2. Prevalence of bilharziasis in relation to personal attributes and habits. Bull World Health Organ. 1966;35:293-318.

35. Huang Y, Manderson L. Schistosomiasis and the social patterning of infection. Acta Trop. 1992;51:175-94.

36. Husting EL. Human water contact activities related to the transmission of bilharziasis (schistosomiasis). J Trop Med Hyg. 1983;86:23-35.

37. Chandiwana SK. Community water-contact patterns and the transmission of Schistosoma haematobium in the highveld region of Zimbabwe. Soc Sci Med. 1987;25:495-505.

38. Butterworth AE. Immunology of schistosomiasis. In: Jordan P, Webbe G, Sturrock RF, editors. Human schistosomiasis. Wallingford: CAB International; 1993. p. 331-66.

39. Costa MFFL, Magalhães MH, Rocha RS, Antunes CM, Katz N. Water-contact patterns and socioeconomic variables in the epidemiology of schistosomiasis mansoni in an endemic area in Brazil. Bull World Health Organ. 1987;65:57-66.

40. Doumenge JP, Mott KE. Global distribution of schistosomiasis: CEGET/WHO atlas. World Health Stat Q. 1987;37:186-99.

41. Clennon JA, Mungai PL, Muchiri EM, King CH, Kitron U. Spatial and temporal variations in local transmission of Schistosoma haematobium in Msambweni, Kenya. Am J Trop Med Hyg. 2006;75:1034-41.

42. Mota E, Sleigh AC. Water-contact patterns and Schistosoma mansoni infection in a rural community in northeast Brazil. Rev Inst Med Trop São Paulo. 1987;29:1-8.

43. Webbe G, Jordan P. Control. In: Jordan P, Webbe G, Sturrock RF, editors. Human schistosomiasis. Wallingford: CAB International; 1993. p. 405-51.

44. Clements ACA, Bosqué-Oliva E, Sacko M, Landouré $A$, Dembélé $R$, Traoré $M$, et al. A comparative study of the spatial distribution of schistosomiasis in Mali in 1984-1989 and 2004-2006. PLoS Negl Trop Dis. 2009;3:e431.

45. Zhang Z, Zhu R, Ward MP, Xu W, Zhang L, Guo J, et al. Long-term impact of the World Bank Loan Project for schistosomiasis control: a comparison of the spatial distribution of schistosomiasis risk in China. PLoS Negl Trop Dis. 2012;6:e1620.

46. Utzinger J, Raso G, Steinmann P, Zhou XN, Vounatsou P, Brooker S, et al. Schistosomiasis. In: Encyclopedia of Environmental Health. Burlington: Elsevier; 2011. p. 10-9.

47. Pflüger W, Roushdy MZ, El Emam M. The prepatent period and cercarial production of Schistosoma haematobium in Bulinus truncatus (Egyptian field strains) at different constant temperatures. Z Parasitenkd. 1984;70:95-103.

48. Upatham ES. Location of Biomphalaria glabrata (Say) by miracidia of Schistosoma mansoni Sambon in natural standing and running waters on the West Indian Island of St. Lucia. Int J Parasitol. 1973;3:289-97.

49. Haas W, Schmitt R. Characterization of chemical stimuli for the penetration of Schistosoma mansoni cercariae. I. Effective substances, host specificity. Z Parasitenkd. 1982;66:293-307.

50. Stirewalt MA, Cousin CE, Dorsey CH. Schistosoma mansoni: stimulus and transformation of cercariae into schistosomules. Exp Parasitol. 1983;56:358-68.

51. Clennon JA, King CH, Muchiri EM, Kitron U. Hydrological modelling of snail dispersal patterns in Msambweni, Kenya and potential resurgence of Schistosoma haematobium transmission. Parasitology. 2007;134:683-93.

52. Beck-Wörner C, Raso G, Vounatsou P, N'Goran EK, Rigo G, Parlow E, et al. Bayesian spatial risk prediction of Schistosoma mansoni infection in western Côte d'Ivoire using a remotely-sensed digital elevation model. Am J Trop Med Hyg. 2007;76:956-63.

53. Utzinger J, Mayombana C, Smith T, Tanner M. Spatial microhabitat selection by Biomphalaria pfeifferi in a small perennial river in Tanzania. Hydrobiologia. 1997;356:53-60.

54. Pitchford RJ, Meyling AH, Meyling J, Du Toit JF. Cercarial shedding patterns of various schistosome species under outdoor conditions in the Transvaal. Ann Trop Med Parasitol. 1969;63:359-71.

55. Utzinger J, N'Goran EK, Caffrey CR, Keiser J. From innovation to application: social-ecological context, diagnostics, drugs and integrated control of schistosomiasis. Acta Trop. 2011;120 Suppl 1:121-37. 
56. Esrey SA, Potash JB, Roberts L, Shiff C. Effects of improved water supply and sanitation on ascariasis, diarrhoea, dracunculiasis, hookworm infection, schistosomiasis, and trachoma. Bull World Health Organ. 1991;69:609-21.

57. Grimes JET, Croll D, Harrison WE, Utzinger J, Freeman MC, Templeton MR. Relationship between water and sanitation, and schistosomiasis: a systematic review and meta-analysis. PLoS Negl Trop Dis. 2014;8:e3296.

58. Bruun B, Aagaard-Hansen J: The social context of schistosomiasis and its control: an introduction and annotated bibliography. Special Programme for Research \& Training in Tropical Diseases (TDR) sponsored by UNICEF/UNDP/ World Bank/WHO 2008:pp 227.

59. Aagaard-Hansen J, Mwanga JR, Bruun B. Social science perspectives on schistosomiasis control in Africa: past trends and future directions. Parasitology. 2009;136:1747-58.

60. Garba A, Barkire N, Djibo A, Lamine MS, Sofo B, Gouvras AN, et al. Schistosomiasis in infants and preschool-aged children: Infection in a single Schistosoma haematobium and a mixed S. haematobium-S. mansoni foci of Niger. Acta Trop. 2010;115:212-9.

61. Ekpo UF, Oluwole AS, Abe EM, Etta HE, Olamiju F, Mafiana CF. Schistosomiasis in infants and pre-school-aged children in sub-Saharan Africa: implication for control. Parasitology. 2012;139:835-41.

62. Seto EY, Sousa-Fiqueiredo JC, Betson M, Byalero C, Kabatereine NB, Stothard JR. Patterns of intestinal schistosomiasis among mothers and young children from Lake Albert, Uganda: water contact and social networks inferred from wearable global positioning system dataloggers. Geospat Health. 2012;7:1-13.

63. Coulibaly JT, N'Gbesso YK, N'Guessan NA, Winkler MS, Utzinger J, N'Goran EK. Epidemiology of schistosomiasis in two high-risk communities of south Côte d'Ivoire with particular emphasis on pre-school-aged children. Am J Trop Med Hyg. 2013;89:32-41.

64. Poole H, Terlouw DJ, Naunje A, Mzembe K, Stanton M, Betson M, et al. Schistosomiasis in pre-school-age children and their mothers in Chikhwawa district, Malawi with notes on characterization of schistosomes and snails. Parasit Vectors. 2014;7:153.

65. Nalugwa A, Olsen A, Tukahebwa ME, Nuwaha F. Intestinal schistosomiasis among preschool children along the shores of Lake Victoria in Uganda. Acta Trop. 2015;142:115-21.

66. Woolhouse MEJ. Patterns in parasite epidemiology: the peak shift. Parasitol Today. 1998;14:428-34.

67. Raso G, Vounatsou P, McManus DP, N'Goran EK, Utzinger J. A Bayesian approach to estimate the age-specific prevalence of Schistosoma mansoni and implications for schistosomiasis control. Int J Parasitol. 2007;37:1491-500.

68. Hewitson JP, Maizels RM. Vaccination against helminth parasite infections. Expert Rev Vaccines. 2014;13:473-87.

69. Bella H, Marshall TFC, Omer AH, Vaughan JP. Migrant workers and schistosomiasis in the Gezira, Sudan. Trans R Soc Trop Med Hyg. 1980;74:36-9.

70. Cheesmond A. Migrant workers and schistosomiasis in the Gezira, Sudan. Trans R Soc Trop Med Hyg. 1980;74:691-2.

71. Koukounari A, Gabrielli AF, Touré S, Bosqué-Oliva E, Zhang Y, Sellin B, et al. Schistosoma haematobium infection and morbidity before and after large-scale administration of praziquantel in Burkina Faso. J Infect Dis. 2007;196:659-69.

72. Utzinger J, Bergquist R, Xiao SH, Singer BH, Tanner M. Sustainable schistosomiasis control - the way forward. Lancet. 2003;362:1932-4.

73. Singer BH, de Castro MC. Bridges to sustainable tropical health. Proc Natl Acad Sci U S A. 2007;104:16038-43.

74. Utzinger J, Raso G, Brooker S, de Savigny D, Tanner M, Ørnbjerg N, et al. Schistosomiasis and neglected tropical diseases: towards integrated and sustainable control and a word of caution. Parasitology. 2009;136:1859-74

75. Spiegel JM, Dharamsi S, Wasan KM, Yassi A, Singer B, Hotez PJ, et al. Which new approaches to tackling neglected tropical diseases show promise? PLoS Med. 2010;7:e1000255.

76. Cross ER, Sheffield C, Perrine R, Pazzaglia G. Predicting areas endemic for schistosomiasis using weather variables and a Landsat data base. Mil Med. 1984;149:542-4.

77. Bergquist $R$, Rinaldi $L$. Health research based on geospatial tools: a timely approach in a changing environment. J Helminthol. 2010;84:1-11.

78. Malone JB, Huh OK, Fehler DP, Wilson PA, Wilensky DE, Holmes RA, et al. Temperature data from satellite imagery and the distribution of schistosomiasis in Egypt. Am J Trop Med Hyg. 1994;50:714-22.
79. Jensen JR. Remote sensing of the environment - an Earth resource perspective. Upper Saddle River: Prentice-Hall; 2000.

80. Abdel-Rahman MS, El-Bahy MM, Malone JB, Thompson RA, El Bahy NM Geographic information systems as a tool for control program management for schistosomiasis in Egypt. Acta Trop. 2001;79:49-57.

81. Brooker S, Hay SI, Issae W, Hall A, Kihamia CM, Lwambo NJ, et al. Predicting the distribution of urinary schistosomiasis in Tanzania using satellite sensor data. Trop Med Int Health. 2001;6:998-1007.

82. Malone JB, Yilma JM, McCarroll JC, Erko B, Mukaratirwa S, Zhou X. Satellite climatology and the environmental risk of Schistosoma mansoni in Ethiopia and East Africa. Acta Trop. 2001;79:59-72.

83. Kristensen TK, Malone JB, McCarroll JC. Use of satellite remote sensing and geographic information systems to model the distribution and abundance of snail intermediate hosts in Africa: a preliminary model for Biomphalaria pfeifferi in Ethiopia. Acta Trop. 2001;79:73-8.

84. Brooker S, Hay SI, Tchuem Tchuenté LA, Ratard R. Using NOAA-AVHRR data to model human helminth distributions in planning disease control in Cameroon, West Africa. Photogramm Eng Rem S. 2002;68:175-9.

85. Kabatereine NB, Brooker S, Tukahebwa EM, Kazibwe F, Onapa AW. Epidemiology and geography of Schistosoma mansoni in Uganda: implications for planning control. Trop Med Int Health. 2004;9:372-80.

86. Malone JB, McNally KL, McCarroll JC, Corbett JD, Mkoji G. Modeling the biocoenose of parasitic diseases using remote sensing and geographic information systems. Parassitologia. 2004;46:59-61.

87. Raso G, Matthys B, N'Goran EK, Tanner M, Vounatsou P, Utzinger J. Spatial risk prediction and mapping of Schistosoma mansoni infections among schoolchildren living in western Côte d'Ivoire. Parasitology. 2005;131:97-108.

88. Raso G, Vounatsou P, Singer BH, N'Goran EK, Tanner M, Utzinger J. An integrated approach for risk profiling and spatial prediction of Schistosoma mansoni-hookworm coinfection. Proc Natl Acad Sci U S A. 2006;103:6934-9.

89. Clements ACA, Lwambo NJ, Blair L, Nyandindi U, Kaatano G, Kinung'hi S, et al. Bayesian spatial analysis and disease mapping: tools to enhance planning and implementation of a schistosomiasis control programme in Tanzania. Trop Med Int Health. 2006;11:490-503.

90. Clements ACA, Moyeed R, Brooker S. Bayesian geostatistical prediction of the intensity of infection with Schistosoma mansoni in East Africa. Parasitology. 2006;133:711-9.

91. Raso G, Vounatsou P, McManus DP, Utzinger J. Bayesian risk maps for Schistosoma mansoni and hookworm mono-infections in a setting where both parasites co-exist. Geospat Health. 2007;2:85-96.

92. Clements ACA, Garba A, Sacko M, Touré S, Dembelé R, Landouré A, et al. Mapping the probability of schistosomiasis and associated uncertainty, West Africa. Emerg Infect Dis. 2008;14:1629-32.

93. Ekpo UF, Mafiana CF, Adeofun CO, Solarin AR, Idowu AB. Geographical information system and predictive risk maps of urinary schistosomiasis in Ogun State, Nigeria. BMC Infect Dis. 2008;8:74.

94. Simoonga C, Kazembe LN, Kristensen TK, Olsen A, Appleton CC, Mubita P, et al. The epidemiology and small-scale spatial heterogeneity of urinary schistosomiasis in Lusaka province, Zambia. Geospat Health. 2008;3:57-67.

95. Brooker S, Clements ACA. Spatial heterogeneity of parasite co-infection: determinants and geostatistical prediction at regional scales. Int J Parasitol. 2009;39:591-7.

96. Clements ACA, Brooker S, Nyandindi U, Fenwick A, Blair L. Bayesian spatial analysis of a national urinary schistosomiasis questionnaire to assist geographic targeting of schistosomiasis control in Tanzania, East Africa. Int J Parasitol. 2008:38:401-15.

97. Clements ACA, Firth S, Dembelé R, Garba A, Touré S, Sacko M, et al. Use of Bayesian geostatistical prediction to estimate local variations in Schistosoma haematobium infection in western Africa. Bull World Health Organ. 2009;87:921-9.

98. Sturrock HJ, Picon D, Sabasio A, Oguttu D, Robinson E, Lado M, et al. Integrated mapping of neglected tropical diseases: epidemiological findings and control implications for northern Bahr-el-Ghazal State, Southern Sudan. PLoS Negl Trop Dis. 2009;3:e537.

99. Koroma JB, Peterson J, Gbakima AA, Nylander FE, Sahr F, Soares Magalhães RJ, et al. Geographical distribution of intestinal schistosomiasis and soil-transmitted helminthiasis and preventive chemotherapy strategies in Sierra Leone. PLoS Negl Trop Dis. 2010;4:e891.

100. Hodges MH, Soares Magalhães RJ, Paye J, Koroma JB, Sonnie M, Clements ACA, et al. Combined spatial prediction of schistosomiasis and soil-transmitted 
helminthiasis in Sierra Leone: a tool for integrated disease control. PLoS Negl Trop Dis. 2012;6:e1694.

101. Soares Magalhães RJ, Biritwum NK, Gyapong JO, Brooker S, Zhang Y, Blair L, et al. Mapping helminth co-infection and co-intensity: geostatistical prediction in ghana. PLoS Negl Trop Dis. 2011;5:e1200.

102. Stensgaard AS, Jorgensen A, Kabatereine NB, Malone JB, Kristensen TK Modeling the distribution of Schistosoma mansoni and host snails in Uganda using satellite sensor data and geographical information systems. Parassitologia. 2005:47:115-25.

103. Stensgaard AS, Jorgensen A, Kabatereine NB, Rahbek C, Kristensen TK. Modeling freshwater snail habitat suitability and areas of potential snail-borne disease transmission in Uganda. Geospat Health. 2006;1:93-104.

104. Schur N, Hürlimann E, Garba A, Traoré MS, Ndir O, Ratard RC, et al. Geostatistical model-based estimates of schistosomiasis prevalence among individuals aged $\leq 20$ years in West Africa. PLoS Negl Trop Dis. 2011;5:e1 194

105. Schur N, Hürlimann E, Stensgaard AS, Chimfwembe K, Mushinge G, Simoonga $C$, et al. Spatially explicit Schistosoma infection risk in eastern Africa using Bayesian geostatistical modelling. Acta Trop. 2013;128:365-77.

106. Schur N, Utzinger J, Vounatsou P. Modelling age-heterogeneous Schistosoma haematobium and S. mansoni survey data via alignment factors. Parasit Vectors. 2011:4:142.

107. Vounatsou P, Raso G, Tanner M, N'Goran EK, Utzinger J. Bayesian geostatistical modelling for mapping schistosomiasis transmission. Parasitology. 2009;136:1695-705.

108. Clennon JA, King CH, Muchiri EM, Kariuki HC, Ouma JH, Mungai P, et al. Spatial patterns of urinary schistosomiasis infection in a highly endemic area of coastal Kenya. Am J Trop Med Hyg. 2004;70:443-8.

109. Bergquist R, Malone JB, Kristensen TK. Schistosomiasis information systems and control of snail-borne diseases. Parasitol Today. 2000;16:363-4.

110. Brooker S, Michael E. The potential of geographic information systems and remote sensing in epidemiology and control of human helminth infections. Adv Parasitol. 2000;47:289-307.

111. Brooker S, Clements ACA, Bundy DAP. Global epidemiology, ecology and control of soil-transmitted helminth infections. Adv Parasitol. 2006;62:221-61.

112. Brooker S. Spatial epidemiology of human schistosomiasis in Africa: risk models, transmission dynamics and control. Trans R Soc Trop Med Hyg. 2007:101:1-8.

113. Bannari A, Morin D, Bonn F, Huete AR. A review of vegetation indices. Remote Sens Rev. 1995;13:95-120.

114. Xu H. Modification of normalised difference water index (NDWI) to enhance open water features in remotely sensed imagery. Int J Remote Sens. 2006;27:3025-33.

115. FAO. GeoNetwork: Find and analyze geo-spatial data [http://www.fao.org/ geonetwork/srv/en/main.home]. Access date 2014 January 14

116. WHO. Prevention and control of schistosomiasis and soil-transmitted helminthiasis. WHO Tech Rep Ser. 2002:912:1-57.

117. Ekpo UF, Hürlimann E, Schur N, Oluwole AS, Abe EM, Mafe MA, et al. Mapping and prediction of schistosomiasis in Nigeria using compiled survey data and Bayesian geospatial modelling. Geospat Health. 2013;7:355-66.

118. Schur N, Vounatsou P, Utzinger J. Determining treatment needs at different spatial scales using geostatistical model-based risk estimates of schistosomiasis. PLoS Negl Trop Dis. 2012;6:e1773.

119. Schur N, Gosoniu L, Raso G, Utzinger J, Vounatsou P. Modelling the geographical distribution of co-infection risk from single-disease surveys. Stat Med. 2011;30:1761-76.

120. Stothard JR, Chitsulo L, Kristensen TK, Utzinger J. Control of schistosomiasis in sub-Saharan Africa: progress made, new opportunities and remaining challenges. Parasitology. 2009;136:1665-75.

121. King CH. Parasites and poverty: the case of schistosomiasis. Acta Trop. 2010;113:95-104

122. Rollinson D, Knopp S, Levitz S, Stothard JR, Tchuem Tchuenté L-A, Garba A, et al. Time to set the agenda for schistosomiasis elimination. Acta Trop. 2013;128:423-40

123. Utzinger J. A research and development agenda for the control and elimination of human helminthiases. PLoS Negl Trop Dis. 2012;6:e1646.

124. WHO. Accelerating work to overcome the global impact of neglected tropical diseases: a roadmap for implementation. Geneva: World Health Organization; 2012

\section{Submit your next manuscript to BioMed Central and take full advantage of:}

- Convenient online submission

- Thorough peer review

- No space constraints or color figure charges

- Immediate publication on acceptance

- Inclusion in PubMed, CAS, Scopus and Google Scholar

- Research which is freely available for redistribution

Submit your manuscript at www.biomedcentral.com/submit 